\title{
Probing EFL Students' Language Skill Development in Tertiary Classrooms
}

\author{
Hong Wang \\ Faculty of Education \\ Mount Saint Vincent University \\ 166 Bedford Highway, Halifax, NS B3M 2J6, Canada
}

Tel: 1-902-457-6192 E-mail: hong.wang@msvu.ca

\begin{abstract}
Research in second or foreign language learning indicates that for adult learners, the improvement of one language skill facilitates the development of other skills. The purpose of this study was to investigate the correlations among Chinese EFL students' reading, writing, and listening development by examining their test scores on the College English Test Band 4. The findings showed that the resultant correlation coefficients between reading and writing and between reading and listening were low and not statistically significant. However, there was a significant relationship between listening and writing. It was suggested that factors such as the homogeneous sample selected, students' motivation, and teaching methodology might affect the outcome of the research. The perceived implications of the research point to the importance of drawing close attention to teachers' efforts in cultivating and developing students' language skills evenly in the EFL context of China.
\end{abstract}

Keywords: Language skill development, Correlation, Reading, Writing, Listening, Chinese students

\section{Introduction}

How adolescents or adults learn a second or foreign language has intrigued researchers in the field of second language acquisition (SLA) for many decades. Research has revealed that children and adults are different in their respective language acquisition, in that children acquire their mother tongue or first language (L1) at an early age, picking it up in the linguistic environment where they are raised (Ellis, 1986, 1990; Lightbown \& Spada, 2006). Adolescent or adult learners simply cannot do so when learning a second or foreign language (L2) not only because the environment for picking up a language in such a way is unavailable, but also because there are many additional factors which pertain to the adult learner, such as age, aptitude, intelligence, cognitive style, motivation, attitudes, learning styles and strategies, and personality (Brown, 2007; Krashen, 1982, 1985; Larsen-Freeman \& Long, 1991; Mitchell \& Myles, 2004). For most adolescents and adults, L2 learning takes place in the classroom, with grammar and reading the first language skills being targeted.

In English as a foreign language (EFL) contexts such as those in Japan, Korea, and China, reading has been the skill most emphasized in both traditional and modern EFL teaching. For example, English instruction at the tertiary level in China is usually the "intensive reading procedure," which consists of close study of short passages, including syntactic, semantic, and lexical analyses, followed by translation into the first language in order to study meaning (Susser \& Robb, 1990). It is suggested from cognitive science that in learning L2 individuals must read and memorize sufficient correctly structured English sentences before they can speak and write them properly (Ellis, 1986, 1990).

For the great majority of EFL students, the development of the four language skills - listening, speaking, reading, and writing - focuses first on reading. Moreover, the school curriculum at various levels in EFL settings has also indicated the priority of cultivating students' reading ability. This can be shown in the fact that the intensive reading (IR) and extensive reading (ER) courses (Note 1) have more hours devoted each week to reading than to listening in Chinese tertiary classrooms. Based on the reality of the teaching circumstances, I proposed two hypotheses when conducting this study: (1) students' high proficiency in reading would result in a high proficiency in writing skills; and (2) students' high proficiency in reading would result in a high proficiency in listening skills. The purpose of the current study, 
therefore, was to examine and explore the relationships between reading, writing, and listening skills, as indicated by students' performance on the nationwide standardized English proficiency test.

\section{Methods}

\subsection{Participants}

The participants selected for this study consisted of 57 sophomores from a Chinese university situated in the large north-western city of Xi'an. These full-time undergraduate non-English-major students are all homogenous Chinese, majoring in computer application in the computer science department. Their age ranged from 19 to 21 . As well, they started their tertiary EFL learning in the fall of 2000 and were observed during the fall term of 2001 when they were studying English at Band 3 (the third term). They expected to complete language studies after two years and four bands (Note 2) before taking the nationwide language proficiency test—-the College English Test Band 4 (CET-4) to be held in June 2002.

The sample was chosen from approximately 3,000 students of the Year 2000 student population. Though simply a convenience sample, the rationale underlying the purposeful selection of such a sample was that the subjects were drawn from a comparatively large class of 57 students. Usually class sizes varied from 30 to 45 students in a "natural class" (Note 3) in the English language courses in this university.

\subsection{Instrument}

The instrument used in this study was the paper-and-pencil-based College English Test Band 4 (CET-4) of June 2000 developed by the College English Band 4/6 Examination Committee, which has been operational since 1987. CET-4 measures the following items: (1) Listening comprehension (20\%) (10 short conversations and 3 short passages with 20 multiple-choice questions), (2) Reading comprehension (40\%) (4 passages with 20 multiple-choice questions), (3) Vocabulary and structure (15\%) (30 multiple-choice questions with $60 \%$ on vocabulary and $40 \%$ on structure), (4) Cloze test (10\%) (20 multiple-choice questions), and (5) Writing (15\%) (one page composition of 120 to 150 words on a given topic to be finished within 30 minutes). This nationwide test mainly employs an objective multiple-choice format (90 questions altogether), which requires an individual to choose correctly from four possible answers to each question.

Yang (2001) reported from his studies that the CET-4/6 have shown high reliability and validity. From the questionnaires obtained, $92 \%$ of EFL teachers in college and universities across the country believe that the CET-4/6 revealed the actual language proficiency of their students (Yang, 2001). In addition, the reported internal reliability coefficient of multiple-choice questions in each CET-4/6 is above .90 , the correlation coefficient between students' actual test results in CET-4/6 and those of what teachers predict is as high as .70 , and the correlation coefficient between the set passing grade of CET-4/6 and that which teachers predict regarding their students is as high as .82 (Yang, 2001). Based on the fact that each year 2.4 million students at tertiary EFL classrooms are involved in language learning and testing, these results obtained from large-scale standardized tests have indicated significant correlations.

\subsection{Data Collection and Analysis}

During a class session in December 2001, all the 57 students were administered the CET-4 of June 2000 in the language lab. This 2-hour test started with part I, listening comprehension, to be completed within 20 minutes, then reading (35 minutes), vocabulary and structure (20 minutes), and finally cloze test (15 minutes). After the spectrum sheets of multiple-choice questions were collected, all the students were required to write a composition of 120-150 words on a given topic within the last 30 minutes. Finally, all the test papers were collected by the instructor to be marked. Multiple-choice questions are marked by a spectrum machine, whereas composition was marked by the instructor according to the scoring standard set by the College English Band 4/6 Examination Committee. These scores were recorded and entered into an SPSS file as a basis for later data analysis.

After the scores from each section of the CET-4 were obtained from each individual out of the sample of 57, each score as a variable representing listening, reading, vocabulary and structure, cloze, or writing was entered into an SPSS file. Two steps of analyses were undertaken. First, descriptive statistics including mean, standard deviation, median, mode, skewness, and kurtosis for each variable of listening, reading, vocabulary, cloze, and writing were collated to better understand the raw data. Secondly, three pairs of scores were then compared for their correlations, and these were: reading and writing, reading and listening, and listening and writing. The resulting correlation coefficients indicated the degree of relationship between the variables.

\section{Results}

\subsection{Descriptive Statistics for Each Variable}

The distribution for the five variables of listening $(20 \%)$, reading (40\%), vocabulary and structure (15\%), cloze (10\%), and writing (15\%) were first examined. The means of the five variables ranged from 5.23 (writing) to 19.19 (reading), and the standard deviations (SD) from 1.25 to 4.47 (see Table 1). The median scores of the five variables were 10, 18, 8 , 
5.5, and 5; the mode scores were 9, 18, 8.5, 6, and 5, respectively. All the skewness and kurtosis values ranged between +1 and -1 , and they were also within the accepted limits $( \pm 2)$, suggesting that the responses for each variable were distributed normally.

\subsection{Correlations between Listening, Reading, and Writing}

The Pearson product-moment correlation coefficients were calculated and presented in Table 2 for the measures of all the five variables. Statistical analysis revealed that there was no significant relationship between reading and listening $(r$ $=.053, p>.05)$, and the resultant correlation coefficient between reading and writing was low and not statistically significant $(r=.021, p>.05)$. However, there was a significant relationship between listening and writing $(r=.423, p$ $<.01)$. The data suggested that students' reading skills were not related to writing and listening, but that students' listening was related to their writing.

\section{Discussion and Conclusion}

The study as represented by the correlation coefficients .021 (between reading and writing) and .053 (between reading and listening) does not agree with the research hypotheses that there was positive correlation between students' reading and writing, and between reading and listening. Such results suggest that students' high proficiency in reading skills is not necessarily an indicator that they tend to be good at listening and writing.

The descriptive results in the current study tend to be associated with the following factors. Firstly, the sample is a convenience sample of 57 students in the EFL course from a university located in the large Chinese city of Xi'an. Since the sample is not selected randomly from the population and is drawn from an average university in the inland area of China, where students' English language proficiency is lower in comparison with top students from top universities, such results may not be generalized beyond the specific sample of the study. Secondly, for several years, educators and researchers in foreign language teaching and learning have hypothesized that to a large extent, successful and unsuccessful L2 learning can be explained by students' levels of motivation and attitudes regarding L2 learning (Gardner, 1985, 1990; Oxford \& Shearin, 1994). Compared to students who major in law, accounting, international business, and international finance and marketing, and who may have the opportunity to work in joint-ventures which require oral and written communication in English, this sample of homogeneous computer science students may not be highly motivated toward putting much effort into the cultivation of listening and writing skills, based on the simple fact that most of them may not expect to use these two English language skills in their later careers.

The results also show that lack of variability in standard deviation tends to lower the correlation between reading and writing and between reading and listening. With reading comprising $40 \%$ of the total test score, listening $20 \%$, and writing $15 \%$, the standard deviation for reading, listening, and writing are $4.47,2.89$, and 1.25 , respectively. There are two possible reasons which may explain this low variability. One is that the sample is a homogeneous group. Usually, the more heterogeneous the sample is, the greater the variability is. The other reason lies in the fact that there is only one rater involved in marking the written compositions. The test scores indicated that the rater was inclined to give most of her students a mean score of 5 points, hence low variability. The statistically significant correlation between listening and writing $(r=.423, p<.01)$ suggests that since these two sub-test scores have close standard deviation, chances are that they might have low or intermediate correlation. However, it does not necessarily imply that students who have strong listening skills write well, or that students who have low listening scores write poorly.

The lack of a clear relationship between reading, listening, and writing in the current study seems to indicate the outcomes of the "eclectic" or "composite" (Cowan et al., 1979) teaching methodology employed in Chinese EFL tertiary classrooms. Since the College English Teaching Syllabus (College English Curriculum Revision Team, 1986, 1999) does not require a specific teaching method to be employed in classrooms, language practitioners can employ any teaching method they prefer, from grammar-translation approach, to audiolingual, to communicative approach. As a result, those who put more emphasis on grammar teaching would be more likely to produce students with strong reading ability but weak listening and writing skills with the overall result being that students' language skills may develop unevenly.

Finally, the current findings of the study suggest that further study involving a bigger sample from a more heterogeneous group from different universities and different departments should be conducted to test the research hypothesis. This research also lends support for the advocated beliefs in contemporary second or foreign language education that language is for communication and that language is best learned and taught through interaction. Therefore, teachers and students should be expected to collaborate both in and outside of classrooms, with a view toward creating a rich language learning environment where different skills can be developed and competence in communications can be nurtured.

\section{References}

Brown, H. D. (2007). Principles of language learning and teaching $\left(5^{\text {th }}\right.$ ed.). White Plains, NY: Pearson Education. 
College English Curriculum Revision Team. (1986). College English teaching syllabus (For Students of Arts and Sciences). Shanghai: Shanghai Foreign Language Education Press.

College English Curriculum Revision Team. (1999). College English teaching syllabus (For Regular College Students). Shanghai: Shanghai Foreign Language Education Press \& Higher Education Press.

Cowan, J. R., Light, R. L., Mathews, B. E. \& Tucker, G. R. (1979). English teaching in China: A recent survey. TESOL Quarterly, 13(4), 465-482.

Ellis, R. (1986). Understanding second language acquisition. New York: Oxford University Press.

Ellis, R. (1990). Instructed second language acquisition: Learning in the classroom. Mass., USA: Basil Blackwell.

Gardner, R. (1985). Social psychology and second language learning: The role of attitudes and motivation. London: Arnold.

Gardner, R. (1990). Attitudes, motivation, and personality as predictors of success in foreign language learning. In T. Parry \& C. Stansfield (Eds.), Language aptitude reconsidered (pp. 179-221). Englewood Cliffs, NJ: Prentice-Hall.

Krashen, S. D. (1982). Principles and practice in second language acquisition. Oxford: Pergamon Press.

Krashen, S. D. (1985). The input hypothesis: Issues and implications. London: Longman.

Larsen-Freeman, D. \& Long, M. (1991). An introduction to second language acquisition research. London: Longman.

Lightbown, P. M. \& Spada, N. (2006). How languages are learned ( $3^{\text {rd }}$ ed.). Oxford: Oxford University Press.

Mitchell, R. \& Myles, F. (2004). Second language learning theories ( $2^{\text {nd }}$ ed.). London, England: Arnold Publishers.

Oxford, R. \& Shearin, J. (1994). Language learning motivation: Expanding the theoretical framework. Modern Language Journal, 78, 12-28.

Susser, B. \& Robb, T. N. (1990). EFL extensive reading instruction: Research and procedure. JALT Journal, 12(2), 161-185.

Yang, H. (2001). Validity of College English Test Band 4 and 6. Retrieved July 24, 2003, from http://www.edu.cn/20010101/837.shtml.

\section{Notes}

Note 1. The intensive reading (IR) course is two hours per week, with the focus on grammar, vocabulary, reading, and writing, and is taught through a written text. The extensive reading (ER) course is two hours per week with the focus on different reading skills.

Note 2. English language learning at the Chinese tertiary level is divided into four bands according to the College English Teaching Syllabus, implemented in 1986. One term is called one band. Students are required to complete four bands, for a total of 280 teaching hours ( 70 hours each term, six hours each week) to fulfill the basic requirements.

Note 3. "Natural class" refers to a class of students who are all admitted in the same year through the Chinese national university entrance examinations with a major in the same field of study such as chemical engineering, history, economic management, etc. and are therefore placed into the same language class.

Table 1. Descriptive Statistics for Each Variable $(\mathrm{N}=57)$

\begin{tabular}{lllllll}
\hline Variables & Mean & SD & Median & Mode & Skewness & Kurtosis \\
\hline Listening & 10.32 & 2.89 & 10 & 9 & -.08 & -.99 \\
Reading & 19.19 & 4.47 & 18 & 18 & .33 & -.19 \\
Vocabulary & 7.82 & 1.53 & 8 & 8.5 & -.53 & .28 \\
Cloze & 5.33 & 1.26 & 5.5 & 6 & -.11 & 1.58 \\
Writing & 5.23 & 1.25 & 5 & 5 & -1.13 & 2.86 \\
\hline
\end{tabular}


Table 2. Correlations between Reading, Listening, and Writing $(\mathrm{N}=57)$

\begin{tabular}{|c|c|c|c|c|c|}
\hline Variables & Listening & Reading & Vocabulary & Cloze & Writing \\
\hline \multicolumn{6}{|l|}{ Listening } \\
\hline Reading & 0.053 & & & & \\
\hline Vocabulary & -0.024 & 0.107 & & & \\
\hline Cloze & 0.258 & 0.239 & 0.126 & & \\
\hline Writing & $0.423 * *$ & 0.021 & 0.054 & 0.194 & \\
\hline
\end{tabular}

$* * p<.01$. 